\title{
Design and Fabrication of an Improved Low Cost Biomass Briquetting Machine Suitable for use in Nigeria
}

\author{
${ }^{1}$ Ejiroghene Kelly Orhorhoro*, ${ }^{1}$ Okonkwo Micheal Chukudi, ${ }^{2}$ Oghoghorie \\ Oghenekevwe and ${ }^{3}$ Monday Erhire Onogbotsere \\ ${ }^{1}$ Faculty of Engineering, University of Benin, Benin City, Nigeria \\ ${ }^{2}$ Faculty of Engineering, Benson Idahosa University, Benin City, Nigeria \\ ${ }^{3}$ Faculty of Engineering, Delta Sate Polytechnic, Otefe-Oghara, Nigeria \\ ${ }^{1}$ kelecom@yahoo.com, ejiroghene.orhorhoro@eng.uniben.edu
}

\begin{abstract}
Briquetting is a mechanical compaction process for increasing the density of bulky materials. Nigeria's current energy requirements for industrial, commercial and domestic needs cannot be met by our national electric grid which at present can only generate $5000 \mathrm{MW}$ for Nigeria growing population. In this research work, an improved low cost biomass briquetting machine was successfully designed and fabricated for local use in Nigeria. Preliminary tests were carried out to determine the compression ratio required (compression pressure) and the type of mould to be used. Design considerations that guided in the generation of a conceptual design that satisfy the functional requirements were established. The briquette machine design was based on mechanical (hydraulic or piston) compression principle. The machine is operated manually by a hydraulic system to generate pressure required for compression. The results obtained from the design calculation reveal that force exerted on plunger $\left(F_{1}\right)$ is $490.5 \mathrm{~N}$, total compaction force of $355.03 \mathrm{~N}$, total compaction pressure of $2 \mathrm{MPa}$, maximum bending stress of $456 \mathrm{MPa}$, projected area of $0.015 \mathrm{~m}^{2}$, total force acting upward exerted by the spring is $654 \mathrm{~N}$ and a pressure of $4.34 \mathrm{MPa}$ is exerted on the compression piston. Analysis carried out on the produced briquette from the biomass (elephant grass) by the fabricated machine reveals that the machine performance is satisfactory. The biomass (elephant grass) had calorific values of $14011.2 \mathrm{KJ} / \mathrm{kg}$ before briquetting. The calorific value increased to $15013.9 \mathrm{KJ} / \mathrm{Kg}$ after formation of briquette. This increase is partly attributed to the moisture content of the biomass.
\end{abstract}

Index Terms- Briquetting, Design, Biomass, Fabrication, Calorific Value

\section{INTRODUCTION}

As reported by the Energy Commission of Nigeria (ECN) in the year 2010 [1], Nigeria's fossil led economy is under severe pressure due to the over-dependence on oil and gas as all the major sectors; industrial, commercial, transportation and residential rely on it [2]. Only oil and gas among the abundant energy resources in Nigeria have so far been well developed, this however should not be so. The bulk of the energy used for cooking for most households in Nigeria is mainly derived from fossil fuel $[3,4,5]$. Irrespective of Nigeria's position as the sixth largest oil producing country, one of Nigeria's fossil fuels (kerosene) for example, used mainly for cooking is produced and delivered at a cost most Nigerians cannot afford [6]. As a result, a greater percentage of the ever-growing population of Nigeria now depends on the country's forest wood as a source of fuel wood (Figure 1) for domestic and small-scale industrial activities in urban, semi urban and rural areas [7]. 
The demand for fuel wood is expected to rise to about $213.4 \times 10^{3}$ metric tons while the supply would have decreased to about $28.4 \times 10^{3}$ metric tons by the year 2030 [8]. Nigeria's forests which is currently extend over 9.6 million hectares have been dwindling rapidly over the past decades. In the year 2013, the rate of deforestation in Nigeria was estimated at $3.7 \%$, which is one of the highest in the world as reported by the United Nation Collaborating Programme on Reducing Emissions from deforestation and forest degradation in developing country [9]. Nonetheless, it is very obvious that reduction in the use of fuel wood will drastically reduce the pressure mounted on the forest, which encourages cutting down/felling of trees that leads to deforestation and in some cases, lead to extinction of wild life. Henceforth, there is need to develop other sources of energy so that energy supply will be available, sustainable, and affordable for average Nigerians.

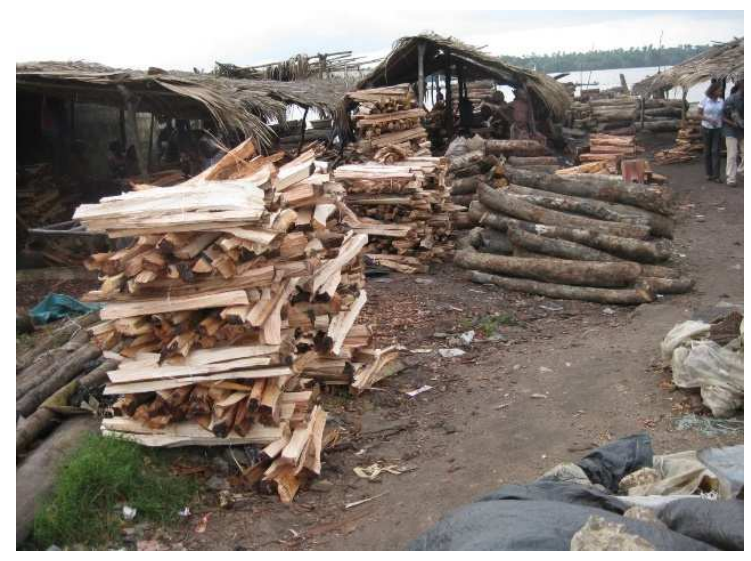

Figure 1: Firewood from Local Market in Nigeria

To address this energy challenge in Nigeria, researchers are exploring other biomass resources namely: energy crops (grasses), agricultural waste, municipal solid waste (MSW) and shrubs as viable feedstock for energy production $[10,11,12,13,14]$. Unlike fossil based fuels, biomass is renewable biodegradable or combustible organic matter generated through life processes which are dependent upon solar energy and this can be sourced cheaply. Biomass is the only renewable energy source which can be used for the production of energy and can equally be converted to other energy carriers like liquid biofuels and pellets [15]. To meet the future energy and climate goals, bioenergy will play a crucial role [16]. Biomass is any organic material that has stored sunlight in the form of chemical energy and these include; plants, agricultural crops or residues, MSW and algae [17]. Biomass resources of Nigeria can be identified as wood, forage grasses and shrubs, animal waste and waste arising from forestry, agricultural, municipal and industrial activities, as well as, aquatic biomass [18]. In many countries like Germany, Brazil, India, China, Canada, Sweden etc. biomass provides $60 \%$ of their energy. However, the technology and energy generation from biomass is still on the low side in Africa and oceanic continent (Figure 2). 


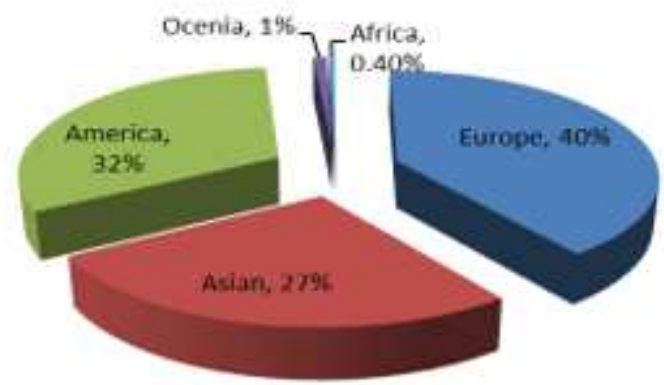

Figure 2: Energy generated from Biomass [19]

Briquetting is a mechanical compaction process for increasing the density of low density materials. This process is used for forming fine particles into a desired shape. It can be regarded as a waste control measure in the case of production of briquettes from agricultural wastes (corncob, rice husk etc.) [20, 21]. However, depending on the material of interest, briquetting can be used to provide fuel or as a preventive measure for many ecological problems. The use of biomass as an alternative source of fuel for heating applications depends mainly on three factors: residue availability for briquetting, adequate technologies and the market for briquettes [22,23]. Although, the significance of biomass briquette as an alternate fuel for wood is widely recognized, the numerous failures of briquetting machines in almost all developing countries have inhibited their extensive exploitation [24]. The constraint in the advancement of biomass briquetting in Nigeria and in developing nations generally is the development of appropriate briquetting technology that suits the local condition; both in terms of the briquetting machine itself for local manufacture and the briquettes [25].

Briquettes are made from bio- waste materials such as dried grasses, old newspaper, sawmill wastes or partially compressed biomass waste. They are largely used as fuel instead of charcoal, firewood or coal. The burning of briquettes depends on the materials used for making them. Briquettes are largely combustible materials made from loose or low density wastes but compressed together into a solid. The compression leads to a product of higher bulk density, uniform size and shape [26,27]. Various briquetting machines have been designed, ranging from very simple types which are manually operated to more complex ones that are mechanically or electrically powered. Generally, briquetting operations have developed in two directions, mechanical compression (hydraulic or pistons) and screw pressing types [28]. In the screw press technology, the biomass is extruded continuously by a screw through a taper die which is heated externally to reduce the friction [29,30]. In mechanical (hydraulic or piston) compression, the biomass is punched into a die by a reciprocating ram compressing the mass to obtain a briquette. The piston press is comparatively older than the screw press [24].

Furthermore, Nigeria is geographically located within the equatorial and tropical region of the world that enjoy high seasonal and regular rainfall and sunshine [20]. Thus, it has vast natural untapped resource of grasses and non- agricultural crops which can be harvested and harnessed in the form of briquettes to serve as a viable and cheap alternative fuel to fossil and fuel wood resources used for commercial and domestic purposes in Nigeria. To achieve this purpose and given our technological knowhow, a low cost briquette machine needs to be designed, fabricated and deployed in Nigeria so as to provide cheap energy, stop deforestation and desertification. 


\section{METHODOLOGY}

Preliminary tests were carried out to determine the compression ratio required (compression pressure) and the type of mould to be used. A plastic bottle of about $50-60 \mathrm{~mm}$ in diameter was obtained to shape the briquette. A tin that fits into the bottle acts as a piston, mortar and pestle were used for size reduction, plastic bag, knife and samples of the grasses and pieces of wires were equally used. The following design requirements were drawn from the preliminary test: mixture ratio, mould design, compression ratio and compression force. Design considerations that guided in the generation of a conceptual designs that satisfy the functional requirements were established, they include; materials used, ease of use, size of the machine, the environment of machine usage, maintenance, safety and cost.

\subsection{Description of the Machine}

The briquette machine design is based on mechanical (hydraulic or piston) compression principle. The biomass is punched into a die by a reciprocating ram compressing it to obtain a briquette [28]. The machine is operated manually by a hydraulic system to generate pressure required for compression. The hydraulic pump has a lever handle that drives hydraulic fluid to creates a pressure differential in the master cylinder. This pushes the piston that compresses loaded biomass in the mould. Figure 3 shows the isometric skeletal view of biomass briquetting machine and Figure 4 shows isometric model view of biomass briquetting machine.

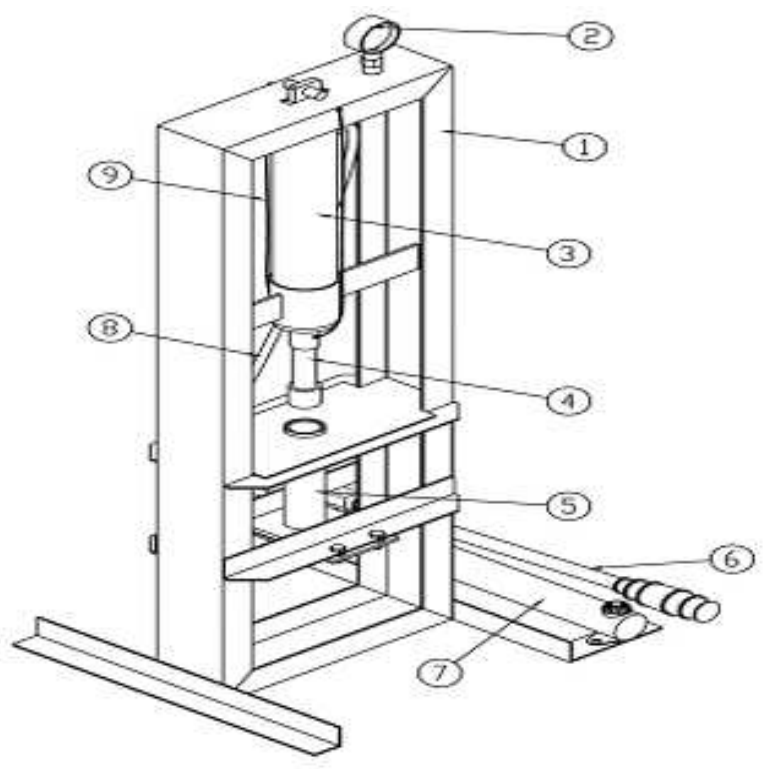

\begin{tabular}{|l|l|}
\hline SNo & DESCRIPTION \\
\hline 1 & Frame \\
\hline 2 & Pressure gauge \\
\hline 3 & Master cylinder \\
\hline 4 & Compression piston \\
\hline 5 & Mould \\
\hline 6 & Hydraulic pump handle \\
\hline 7 & Pumpoil sump \\
\hline 8 & Hydraulic hose \\
\hline 9 & Cylindrical tension spring \\
\hline
\end{tabular}

Figure 3: Isometric Skeletal View of Biomass Briquetting Machine 


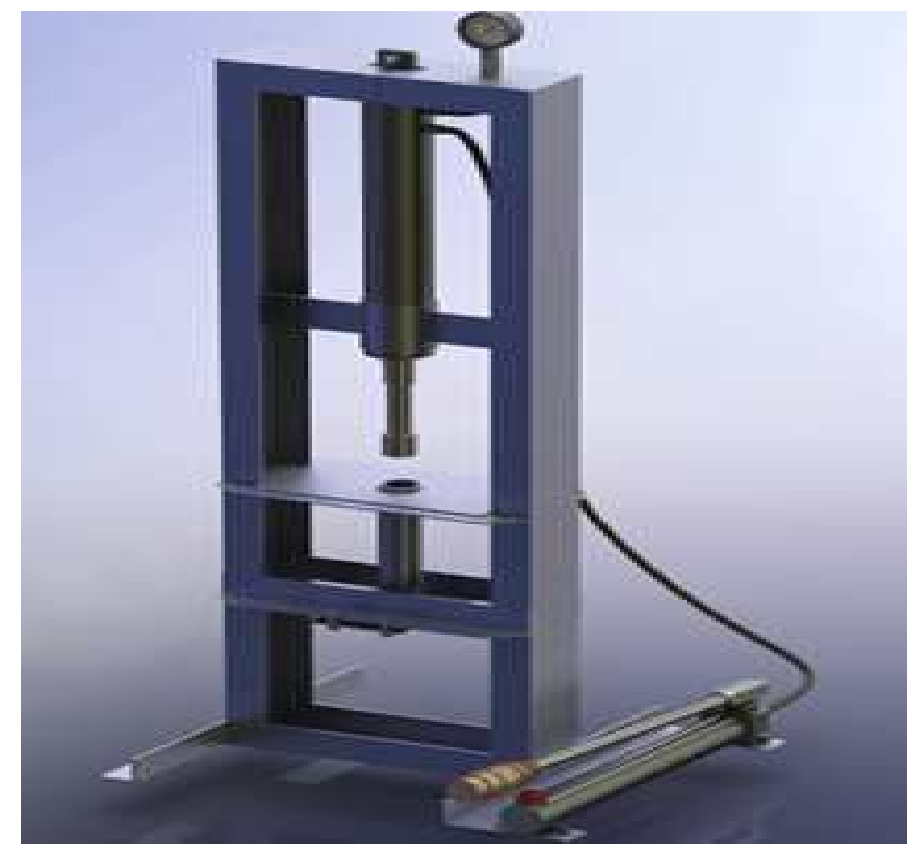

Figure 4: Isometric Model View of Biomass Briquetting Machine

The hydraulic briquetting press consists of five main parts; main frame and mould, helical cylindrical tension spring, piston rod base plate, and a hydraulic system which include: fluid tank, cylinders (slave and master cylinder) and the hydraulic pipe. The main frame was made from $75 \mathrm{~mm}$ x $10 \mathrm{~mm}$ flat bar and 40 $\mathrm{mm} \times 50 \mathrm{~mm}$ angle bars of various length all welded together to produce a rectangular shape of dimension $1155 \mathrm{~mm} \times 300 \mathrm{~mm} \times 80 \mathrm{~mm}$. The mould is located at the lower part of the frame and is made from $10 \mathrm{~mm}$ thick mild steel (one end open cylinder). There are two helical tension springs attached on both side of the frame. Steel wire of thickness $2 \mathrm{~mm}$ is coiled to form a spring with free spring length $\left(\mathrm{L}_{\mathrm{o}}\right)$ of $350 \mathrm{~mm}$. The base plate is a rectangular structure made of mild steel with a thickness of $2 \mathrm{~mm}$. It has an area of $130 \mathrm{~mm}$ $\times 120 \mathrm{~mm}$. The hydraulic system serves as a mechanism used in transmitting force/pressure. The hydraulic piston is pushed in a downward stroke, transmitting an enormous force to facilitate compaction of the material and also function in removing of compressed briquette from the mould. A cylindrical helical tension spring was used as a retraction mechanism for the compression piston. The spring is made up of carbon steel hard drawn wire. This is the cheapest general purpose spring steel and it should only be used where life, accuracy and deflection are not important. This material is available in sizes $0.8 \mathrm{~mm}$ to $12 \mathrm{~mm}$. It has an operating range of 0 to $120^{\circ} \mathrm{C}$.

\subsection{Detailed Design}

The calculated parameters obtain from detail design are show in Table 1. 
INTERNATIONAL JOURNAL OF ENGINEERING TECHNOLOGY AND SCIENCES (IJETS) Vol.8 (1) Dec 2017

DOI: http://dx.doi.org/10.15282/ijets.8.2017.1.11.1086

Table 1: Calculated Parameters

\begin{tabular}{lll}
\hline Parameter & Symbol & Calculated Data \\
\hline Force exerted on plunger $\left(\mathrm{F}_{1}\right)$ & $\mathrm{N}$ & 490.5 \\
Pressure exerted on the plunger $\left(\mathrm{P}_{1}\right)$ & $\mathrm{MPa}$ & 4.34 \\
Pressure exerted on the compression piston $\left(\mathrm{P}_{2}\right)$ & $\mathrm{MPa}$ & 4.34 \\
Force exerted on compression piston $\left(\mathrm{F}_{2}\right)$ & $\mathrm{N}$ & 984.5 \\
Base area of the compression/ extrusion piston & $\mathrm{m}^{2}$ & 0.000227 \\
Weight of piston & $\mathrm{N}$ & 24.53 \\
Tension exerted by the spring & $\mathrm{N}$ & 327 \\
Total force acting upward exerted by the spring & $\mathrm{N}$ & 654 \\
Total compaction force & $\mathrm{N}$ & 355.03 \\
Maximum bending stress & $\mathrm{MPa}$ & 456 \\
Extension spring constant & $\mathrm{N} / \mathrm{mm}$ & 0.0654 \\
Maximum thickness of base plate & $\mathrm{mm}$ & 1.67 \\
Projected area & $\mathrm{m}^{2}$ & 0.015 \\
\hline
\end{tabular}

\section{TEST AND EVALUATION}

\subsection{Determination of Moisture Content of Biomass (Elephant Grass)}

The moisture content of the biomass is given by Equation (1)

Moisture Content $(\%)=\frac{\text { loss in mass of sample }}{\text { initial mass of sample }} \times \frac{100}{1}$

The moisture content of the biomass was determine using laboratory electric oven (Figure 5). During the process, empty dried crucibles were weighed and a small quantity of each material was placed in each crucible. Mass of the sample plus crucible was determined. The crucibles and their contents were placed in an electric oven, set at a temperature of $110^{\circ} \mathrm{C}$ for one hour. They were brought out, allowed to cool in a desiccator and re-weighed.

Mass of crucible $=16.4 \mathrm{~g}$

Mass of Elephant grass + crucible before heating at $110^{\circ} \mathrm{C}=750 \mathrm{~g}$

Mass of Elephant grass + crucible after heating at $110^{\circ} \mathrm{C}=600.1 \mathrm{~g}$

Temperature of the Electric Oven $=110^{\circ} \mathrm{c}$

Moisture Content (M. C) $=\frac{750-600.1}{750} \times 100=20 \%$ 


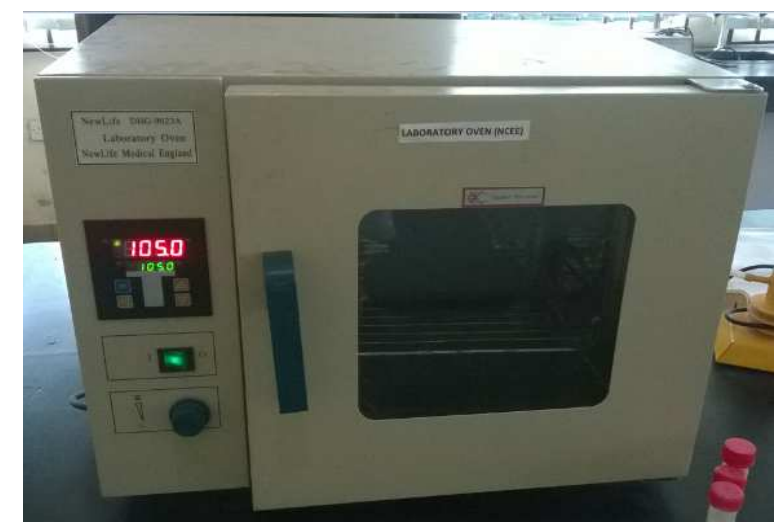

Figure 5: Laboratory Electric Oven

\subsection{Determination of the Calorific Value}

The calorific value of materials was determined using "XRY - 1A" digital oxygen bomb calorimeter (Figure 6).

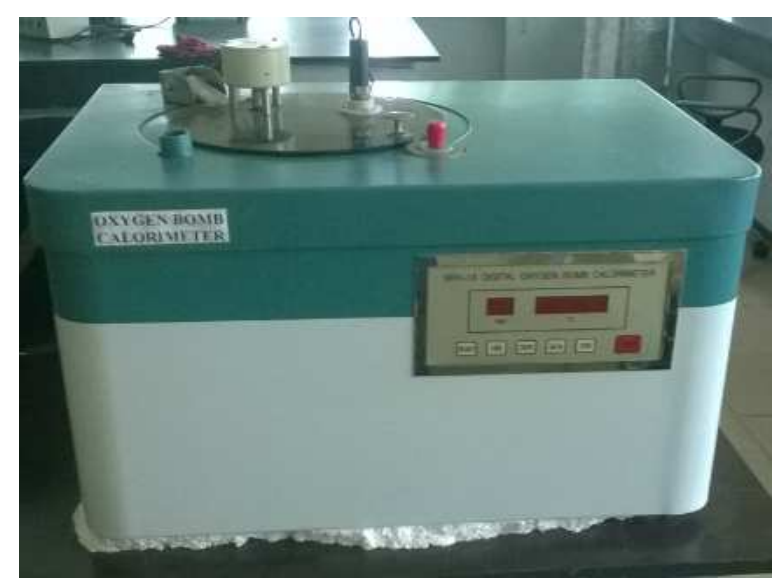

Figure 6: Digital Oxygen Bomb Calorimeter

\section{RESULTS AND DISCUSSION}

Briquetting is a mechanical compaction process for increasing the density of bulky materials. The process is used for forming fine particles into a designed shape. It can be regarded as a waste control measure in the case of production of briquettes from agricultural wastes (grasses, corncob etc.). In this research work, an improved low cost biomass briquetting machine was successfully designed and fabricated for local use in Nigeria. Preliminary tests were carried out to determine the compression ratio required (compression pressure) and the type of mould to be used. Design considerations that guided in the generation of a conceptual designs that satisfy the functional requirements were established. The briquette machine design is based on mechanical (hydraulic or piston) compression principle. The machine is operated manually by a hydraulic system to generate pressure required for compression. The detail design and fabrication were based on the following criteria; functionality, 
simplicity, cost, and maintenance. The results obtained from design calculation reveal that the weight of piston $\left(\mathrm{F}_{3}\right)$ is $24.53 \mathrm{~N}$, the force exerted on plunger $\left(\mathrm{F}_{1}\right)$ was gotten to be $490.5 \mathrm{~N}$, the extension spring constant $(\mathrm{k})$ calculated for is $0.0654 \mathrm{~N} / \mathrm{mm}$, tension extended by the spring $(\mathrm{T})$ is $327 \mathrm{~N}$, total compaction force $\left(\mathrm{F}_{\mathrm{T}}\right)$ of $355.03 \mathrm{~N}$, maximum thickness of base plate $\left(\mathrm{t}_{\mathrm{b}}\right)$ of $1.67 \mathrm{~mm}$, total compaction pressure $\left(\mathrm{P}_{\mathrm{C}}\right)$ of $2 \mathrm{MPa}$ was achieved, the maximum bending stress recorded was $456 \mathrm{MPa}$, projected area of $0.015 \mathrm{~m}^{2}$ is established, total force acting upward exerted by the spring is $654 \mathrm{~N}$ and a pressure of $4.34 \mathrm{MPa}$ was exerted on the compression piston. The designed machine was fabricated and performance evaluation carried out on the end product (Figure 7).

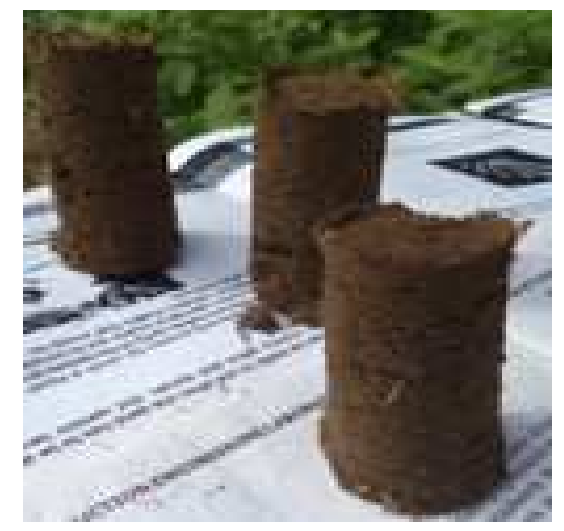

Figure 7: Sample Elephant Grass Briquette

The biomass (elephant grass) had calorific values of $14011.2 \mathrm{KJ} / \mathrm{kg}$ before briquetting. The calorific value increased $15013.9 \mathrm{KJ} / \mathrm{Kg}$ after formation of briquette. This increase is partly attributed to the moisture content of elephant grass. Positive results were obtained when compared to fuel woods from forest and coal currently being used, with a low level of fixed carbon, less ash and sulphur content. The cost of materials used for the fabrication of the biomass briquetting machine is shown in Table 4. The total cost in naira was thirty-nine thousand, two hundred and sixty ( $\$ 39,260)$ in Nigeria currency. At the time of this research work, the exchange rate of naira to dollar is three hundred and sixty-three naira to one dollar ( $1 \$=\$ 363)$. In other words, approximately one hundred and eight US dollar $(108 \$)$ was used for the fabrication of the biomass briquette machine. Therefore, the fabricated biomass briquette machine is of low cost.

The machine through put capacity is given Equation (2),

$\mathrm{MTC}=\frac{\mathrm{M}}{\mathrm{T}_{(\mathrm{s})}}$

Where,

MTC $=$ Machine through put capacity

$\mathrm{M}=$ Mass of Elephant Grass Briquette

$\mathrm{T}(\mathrm{s})=$ Time required to produce Elephant Grass Briquette

The average mass of produce elephant grass briquette and time required to produce biomass briquette from elephant grass were calculated from Equation (3). Table 2 and Table 3 show the 
INTERNATIONAL JOURNAL OF ENGINEERING TECHNOLOGY AND SCIENCES (IJETS) Vol.8 (1) Dec 2017 DOI: http://dx.doi.org/10.15282/ijets.8.2017.1.11.1086

results obtained for moisture content of elephant grass and twelve (12) samples of biomass briquette produced from elephant grass.

Table 2: Result of Proximate Analysis of Elephant Grass

\begin{tabular}{ccc}
\hline Moisture Content $(\%)$ & \multicolumn{2}{c}{ Calorific Value $(\mathrm{KJ} / \mathrm{Kg})$} \\
\hline 20.00 & Before & After \\
\cline { 2 - 3 } & 14011.2 & 15013.9 \\
\hline
\end{tabular}

Table 3: Result obtained with Briquette Machine

\begin{tabular}{llll}
\hline Samples & $\mathrm{M}(\mathrm{kg})$ & $\mathrm{T}_{(\mathrm{s})}$ & $\mathrm{MTC}(\mathrm{kg} / \mathrm{s})$ \\
\hline 1 & 2.04 & 64.00 & 0.0319 \\
2 & 1.87 & 59.25 & 0.0316 \\
3 & 2.05 & 65.12 & 0.0315 \\
4 & 2.10 & 66.01 & 0.0318 \\
5 & 1.99 & 60.35 & 0.0330 \\
6 & 1.94 & 60.05 & 0.0323 \\
7 & 1.78 & 52.45 & 0.0339 \\
8 & 2.01 & 61.95 & 0.0324 \\
9 & 2.02 & 63.45 & 0.0318 \\
10 & 2.12 & 68.34 & 0.0310 \\
11 & 2.25 & 70.01 & 0.0321 \\
12 & 1.05 & 45.25 & 0.0232 \\
$\sum$ & 23.22 & 736.23 & 0.0315 \\
Average & 1.935 & 61.35 & 0.0315 \\
\hline
\end{tabular}

Table 4: Bill of Engineering Materials and Evaluation

\begin{tabular}{|c|c|c|c|c|c|c|}
\hline $\mathbf{N}$ & Component & Material & Dim. (mm) & $\mathbf{Q}$ & UC (\#) & TC (¥) \\
\hline 1 & Angle bar & Mild & Length:540 & 1 & 1200 & 1200 \\
\hline 2 & Solid shaft & Mild steel & Length:294 & 1 & 3000 & 3000 \\
\hline 3 & Flat plate & Mild & Length: 120 & 1 & 4000 & 4000 \\
\hline 4 & Pressure & Pिlastic & $\hat{\mathrm{N}} / \mathrm{A}$ & 1 & 4000 & 4000 \\
\hline 5 & Bolt and Nut & Mild & 13 & 3 & 20 & 60 \\
\hline 6 & Electrode & $\tilde{\mathrm{N}} / \mathrm{A}^{*}$ & N/A & 6 & - & 1000 \\
\hline 7 & Hydraulic & $\mathrm{N} / \mathrm{A}$ & $\mathrm{N} / \mathrm{A}$ & $\hat{1}$ & 25000 & 25000 \\
\hline 8 & Ċylindrical & Mild & Length:280 & 2 & 500 & 1000 \\
\hline Total & & & & & & 39260 \\
\hline
\end{tabular}

*Dim-Dimension, *Q-Quantity, *UC-Unit Cost, *TC-Total Cost, *N-Serial Number

An average mass of $1.935 \mathrm{~kg}$ of biomass briquette was formed from elephant grass and it took 61.35 seconds for its production. The average machine through put capacity was determined as $0.0315 \mathrm{~kg} / \mathrm{sec}$. 
INTERNATIONAL JOURNAL OF ENGINEERING TECHNOLOGY AND SCIENCES (IJETS) Vol.8 (1) Dec 2017

DOI: http://dx.doi.org/10.15282/ijets.8.2017.1.11.1086

\section{CONCLUSION}

The use of biomass briquettes for both industrial and domestic purposes constitutes an important alternative fuel that should be further developed as it allows for the diversification of Nigeria's already strained fossil fuel economy, economic revaluation of biomass waste and the mitigation of greenhouse gas emissions. Performance analysis of the designed and fabricated briquette machine indicated positive results when compared to fuel woods from forest and coal currently being used, with a low level of fixed carbon, similar levels of calorific power $(15013.9 \mathrm{KJ} / \mathrm{Kg})$, less ash and sulphur content, promoting a healthier environment for the consumers making it a good fuel alternative. From the cost analysis, the biomass briquetting machine is of low cost and affordable.

\section{REFERENCES}

[1] Orhorhoro, E.K., Orhorhoro, O.W., and Ogini, M.E., "Assembly and Investigation of Solar Powered Air Conditioner for Household Use in Nigeria", International Academic Journal of Innovative Research, Vol. 3, No. 10, pp. 84-99, 2016

[2] Orhorhoro, E.K., Ebunilo, P.O., Tamuno, R.I., and Essienubong, I.A., "The Study of Anaerobic Co-Digestion of Non-Uniform Multiple Feed Stock Availability and Composition in Nigeria". European Journal of Engineering Research and Science, (EJERS), Vol. 1, No.1, pp.39-42, 2016.

[3] Akinbami, J.F.K., "Renewable Energy Resources and Technologies in Nigeria: Present Situation, Future Prospects and Policy Framework". Migration and Adaptation Strategies for Global Changes (6): pp. $155-181,2001$.

[4] Ebunilo, P.O., Aliu, S.A. and Orhorhoro, E.K., "Performance Study of a Biogas Pilot Plant using Domestic Wastes from Benin Metropolis". International Journal of Thermal \& Environmental Engineering, volume 10, No 2, pp.135-141, 2015

[5] Orhorhoro, E.K., Ebunilo, P.O., and Ikpe, A.E., "Effect of pH on Anaerobic Digestion (AD) of Organic Municipal Solid Waste in Benin City, Nigeria. Journal of the Nigerian Association of Mathematical Physics. Volume 36, No.1, pp. 369-374, 2016

[6] The United Nations Collaborative Programme on Reducing Emissions from Deforestation and Forest Degradation in Developing Countries (UN-REDD). (2011) REDD+ Strategy Programme.

[7] Orhorhoro, E.K, Orhorhoro, O.W and Ebunilo, P.O., "Analysis of the effect of carbon/nitrogen $(\mathrm{C} / \mathrm{N})$ ratio on the performance of biogas yields for non-uniform multiple feed stock availability and composition in Nigeria". International Journal of Innovative Science, Engineering \& Technology, Vol. 3 Issue 5, pp.119-126, 2016.

[8] Adegbulugbe, A.O., "Bioenergy for Development - Technical and Environmental Dimensions". Environmental and Energy. Series No 13, 1994

[9] Adegoke, C.O., "A Preliminary Investigation of Sawdust as High Grade Solid Fuel. Nigerian Journal of Renewable Energy. Vol. 9. pp. 103, 1999

[10] Tunde, O., Titilayo, A., Kunle, A., Femi, O., Adelana, A., "Energy Crisis in Nigeria: Need for Renewable Energy Mix". American Journal of Electrical and Electronic Engineering, Vol. 4, No. 1, $1-8,2016$

[11] Simonyan K.J. and Fasina O., "Biomass resources and bioenergy potentials in Nigeria". Africa Journal of Agricultural research, Vol. 8(40), pp. 4975-4989, 2013

[12] Qiao, W., Yan, X., Ye, J., Sun, Y., Wang, W., and Zhang, Z., "Evaluation of biogas production from different biomass wastes with/without hydrothermal pretreatment". Renewable Energy, 36, pp.3313-3318 
INTERNATIONAL JOURNAL OF ENGINEERING TECHNOLOGY AND SCIENCES (IJETS) Vol.8 (1) Dec 2017 DOI: http://dx.doi.org/10.15282/ijets.8.2017.1.11.1086

[13] Orhorhoro, E.K., Ebunilo, P.O.B., and Sadjere, E.G., "Design of Bio-Waste Grinding Machine for Anaerobic Digestion (AD) System". European Journal of Advances in Engineering and Technology, 4 (7): pp.560-568, ISSN: 2394 - 658X, 2017

[14] Ebunilo, P.O., Aliu, S.A. and Orhorhoro, E.K., "Comparative Analysis of Biogas Yield from Different Composition of Domestic Wastes from Benin City, Nigeria”. Journal of Advanced \&Applied Science (JAAS) Volume 04, Issue 05, Page 169-177, 2015.

[15] World Energy Council, "World Energy Issues Monitor; a Climate of Innovation-Responding to the Commodity price storm", 2015, Retrieved from www.worldenergy.0rg, [Accessed September 13 ${ }^{\text {th }}$, 2016.

[16] Tunde, O., Titilayo, A., Kunle, A., Femi, O., Adelana, A., "Energy Crisis in Nigeria: Need for Renewable Energy Mix". American Journal of Electrical and Electronic Engineering, Vol. 4, No. 1, $1-8,2016$

[17] Human Development Index, "Work for Human Development". Human Development Report 2015, Retrieved from http://hdr.undp.org/sites/default/files/2015_human_development_report.pdf [Accessed 12 ${ }^{\text {th }}$ June, 2016]

[18] Okafor, E.N.C. and Uzuegbu, J., "Challenges to Development of Renewable Energy for Electric Power Sector in Nigeria". International Journal of Academic Research, Vol. 2, No. 2., pp.5-14

[19] IEA BIOENERGY TASK 37, REVAQ Certified Wastewater Treatment Plants in Sweden for Improved Quality of Recycled Digestate Nutrients, Case Study, April 2015. Available from: http://www.iea-biogas.net/case-studies.html

[20] Ebunilo, P.O., Orhorhoro, E.K., Chukwudi, C.M., and Essienubong, A.I., "Performance Evaluation of Biomass Briquette from Elephant and Spear grassin Benin City, Edo State, Nigeria", European Journal of Engineering Research and Science, EJERS, Vol. 1, No. 1, pp.15-17, July 2016

[21] Adegoke, C.O., "A Preliminary Investigation of Sawdust as High Grade Solid Fuel.", Nigerian Journal of Renewable Energy. Vol. 9. pp. 103, 1999

[22] Felfli, F. F., Mesa P, J. M., Rocha, J. D., Filippetto, D., Luengo, C. A. and Pippo, W. A., "Biomass Briquetting and its Perspectives in Brazil". Biomass and Energy (35): pp.236 - 242, 2011

[23] Sotannde, O. A., Oluyege, A. O. and Abah, G. B., "Physical and Combustion Properties of Briquettes from Sawdust of Azadirachta indica", Journal of Forestry Research, 21(1): pp.63 - 67, 2011 [24] Oladeji1, J. T. and Enweremadu, C. C., "The Effects of Some Processing Parameters on Physical and Densification Characteristics of Corncob Briquettes", International Journal of Energy Engineering, 2(1): pp.22-27, 2012

[25] Obi, O. F., Akubuo, C. O., Okonkwo, W. I., "Development of an Appropriate Briquetting Machine for Use in Rural Communities", International Journal of Engineering and Advanced Technology (IJEAT) ISSN: 2249 - 8958, Volume-2, Issue-4, pp.578-582, 2013

[26] Arinola, B.A., Justina, I.O., "Design of Sawdust Briquette Machine”, Innovative Systems Design and Engineering, Vol.4, No.10, pp.51-58, 2013

[27] Yousif A.A., Ahmed E.A., "Experimental evaluation of a conical-screw briquetting machine for the briquetting of carbonized cotton stalks in Sudan", Journal of Engineering Science and Technology Vol. 1, No. 2, pp.212- 220, 2006

[28] Inegbenebor, A.O., "Production of Solid Fuel Briquettes from Agricultural and Wood Waste (sawdust and rice husk)". African Journal of Science and Technology. Vol. 3 No. 2. pp118 - 122.

[29] Miah, A., Huda, D. and Baqui, M. A., "Rice Husk Briquette as Alternative Fuel in Bangladesh. Agricultural Mechanization in Africa and Latin America (AMA). Vol. 30, No. 2. pp 63 - 68, 1999

[30] Olle, F. and Olof, N., "Biomass Briquettes in Malawi, Degree Project, Department of Management and Engineering, Institute of Technology, Linkoping University, Malawi, 2006 